\title{
First Case of Natural Infection in Pigs. Review of Trypanosoma cruzi Reservoirs in Mexico
}

\section{Paz María Salazar-Schettino ${ }^{+}$, Martha Irene Bucio, Margarita Cabrera, Jacobo Bautista}

\author{
Departamento de Microbiología y Parasitología, Laboratorio de Biología de Parásitos, Universidad Nacional \\ Autónoma de México, Facultad de Medicina, Edificio A 2o. Piso, Ciudad Universitaria, Mexico, D.F.
}

An epidemiological research project was performed in the State of Morelos including collection of samples for blood smears and culture, serological tests, and xenodiagnoses from a total of 76 domestic and peridomestic mammals. Two strains of Trypanosoma cruzi were isolated by haemocultures; one from a pig (Sus scrofa), the first case of natural infection reported in Mexico, and the other from a dog (Canis familiaris). This study summarizes current information in Mexico concerning confirmed reservoirs of $\mathrm{T}$. cruzi.

Key words: Trypanosoma cruzi - reservoir - xenodiagnosis - mammal - pig - Mexico

The epidemiological cycle of Trypanosoma cruzi involves humans, the transmitting arthropod, and a large number of different naturally infected mammals. Mammals play an important role as reservoirs, specifically due to their close relationship with triatomines.

The importance of the three mammalian cycles, wild, peridomestic, and domestic is well known; however, the present study concentrates on the peridomestic cycle because it links the other two, favouring that transmission of the parasite can be transferred from wild mammals to humans.

Luis Mazzotti (1940) reported the first two $T$. cruzi infected vertebrates in Mexico: a dog (Canis familiaris) in the State of Oaxaca, and an armadillo (Dasypus novemcinctus) in the State of Colima. Aguirre-Pequeño (1947) reported an infected opossum (Didelphis marsupialis) in the State of Nuevo León and Perrín et al. (1947) reported the same finding in the State of Michoacán. Mazzotti and Dias (1949) discussed the natural infection of T. cruzi in an armadillo and in a dog. Beltrán (1949) reported infection in the Norwegian rat (Rattus norvegicus) in Mexico City. Velasco-Castrejón et al. (1976) confirmed the dog as a reservoir of this parasite. Tay et al. (1979) reported to have identified infection in the mouse

\footnotetext{
This work was supported by grant from PAPIIT-UNAM IN 210189.

${ }^{+}$Corresponding author. Fax: 915-6232468. E-mail: pazmar@servidor.unam.mx

Received 18 December 1996

Accepted 13 May 1997
}

(Mus musculus) and in the squirrel (Scirus vulgaris) in the State of Jalisco. The ox (Bos taurus) was confirmed as reservoir in the District of Jiutepec, State of Morelos (Guzmán-Bracho 1985). Eight cat (Felis domesticus) specimens with positive serology were reported by Salazar-Schettino et al. (1987). Other species from which T. cruzi has been isolated are two country mice (Sigmodon hispidus and Ototylomys phyllotis), an arboreal mouse (Tyloma nudicaudus), and the fruit eater bat (Carrollia perspicillata), which were reported by Zárate and Zárate (mentioned by Domínguez \& Espinoza in 1988). Another species, the donkey (Equus asinus) in the State of Oaxaca (cited by Galaviz-Silva et al. in 1992), and two mice of the genus Liomys, in the State of Morelos, were reported by Parra et al. (1990) and Salazar-Schettino et al. (1990). Perommyscus was reported by Parra et al. (1990) and confirmed by Espinoza-Medinilla et al. (1992) in the State of Chiapas. In 1990, Cruz-Reyes (cited by Velasco-Castrejón in 1991) isolated T. cruzi from a marten (Phylander opossum) in the State of Veracruz. The country rat (Neotoma micropus) was first reported infected in the State of Nuevo León by means of xenodiagnoses (Galaviz-Silvaet al. 1992).

There had been no reports of naturally infected pigs (Suis scrofa) in Mexico until the present study, although Brumpt et al. (1939) suspected that pigs could be infected with T. cruzi (Table I).

\section{MATERIALS AND METHODS}

Animal sampling procedure - For T. cruzi isolation and serology tests, $4 \mathrm{ml}$ of peripheral venous blood was obtained by punction of 76 domestic and peridomestic mammals of the following spe- 
TABLE I

Natural infection with Trypanosoma cruzi of mammals (not humans) in Mexico (1940-1992)

\begin{tabular}{|c|c|c|}
\hline Reservoirs & Authors and year & State \\
\hline Canis familiaris (dog) & Mazzotti 1940 & Oaxaca \\
\hline Dasypus novemcinctus mexicanus (armadillo) & Mazzotti 1940 & Colima \\
\hline \multirow[t]{2}{*}{ Didelphis marsupialis (opossum) } & Aguirre-Pequeño et al. 1947 & Nuevo León \\
\hline & Perrín et al. 1947 & Michoacán \\
\hline Rattus norvegicus (norwegian rat) & Beltrán 1949 & Distrito Federal \\
\hline Mus musculus (mouse) & Tay et al. 1979 & Jalisco \\
\hline Scirus vulgaris (squirrel) & Tay et al. 1979 & Jalisco \\
\hline Bos taurus (ox) & Guzmán-Bracho 1985 & Morelos \\
\hline Felis domesticus (cat) & Salazar-Schettino et al. 1987 & Oaxaca \\
\hline Sigmodon hispidus (country mouse) & $\begin{array}{l}\text { Zárate \& Zárate } \\
\text { (cited by Dominguez \& Espinoza 1988) }\end{array}$ & Not mentioned \\
\hline Ototylomys phyllotis (country mouse) & $\begin{array}{l}\text { Zárate \& Zárate } \\
\text { (cited by Dominguez \& Espinoza 1988) }\end{array}$ & Not mentioned \\
\hline Tyloma nudicaudus (arboread mouse) & $\begin{array}{l}\text { Zárate \& Zárate } \\
\text { (cited by Dominguez \& Espinoza 1988) }\end{array}$ & Not mentioned \\
\hline Carrollia perspicillata (fruit eater bat) & $\begin{array}{l}\text { Zárate \& Zárate } \\
\text { (cited by Dominguez \& Espinoza 1988) }\end{array}$ & Not mentioned \\
\hline Liomys (country mouse) & Parra et al. 1990 & Morelos \\
\hline Perommyscus (country mouse) & Parra et al. 1990 & Morelos \\
\hline Phylander opossum (marten) & $\begin{array}{l}\text { Cruz-Reyes } 1990 \\
\text { (cited by Velasco-Castrejon 1991) }\end{array}$ & Veracruz \\
\hline Equus asinus (donkey) & Galaviz-Silva et al. 1992 & Oaxaca \\
\hline Neotoma micropus (country mouse) & Galaviz-Silva et al. 1992 & Nuevo Leon \\
\hline
\end{tabular}

cies: 49 canines, 20 porcines, 4 bovines, 2 ovines, and 1 caprine.

Culture method - Tubes of $20 \mathrm{ml}$ with NNN (Novy, Mac Neal and Nicolle) culture medium were inoculated with $2 \mathrm{ml}$ of the samples obtained and incubated at $28^{\circ} \mathrm{C}$, shaked every $48 \mathrm{hr}$, and verified every week for 3 months.

Examination of slides - Blood smears (smear test) and thick drop were stained with Romanowsky dyes (Wright-Giemsa).

Xenodiagnosis - Xenodiagnosis was performed in all the sampled animals and exposed to five nymphs at the fifth stage of Triatoma pallidipennis; they were examined individually every week during four months. The triatominae were fed directly by letting them suck on pigeon blood.

Serological test - A blood sample was collected from each animal and placed on two circles of 1.6 $\mathrm{cm}$ diameter of filter-paper (Whatman No. 1). After drying at room temperature, the filter-papers were stored at $4{ }^{\circ} \mathrm{C}$. For serological testing, one circle was cut out and eluted with $0.25 \mathrm{ml}$ of 0.01 $\mathrm{mol} / \mathrm{l}$ phosphate-buffered saline (PBS) for $24 \mathrm{hr}$ to obtain a final dilution of $1: 10$. Eluates were tested using indirect haemagglutination.
Inoculation of experimental animals - Ten female CD-1 mice, weighing 18-20 g, were infected intraperitoneally with a single inocule of $1 \times 10^{6}$ bloodstream trypomastigotes from another mouse previously inoculated with epimastigotes from the first culture medium.

Histopathological examination - Histopathological studies of the heart, brain, lung, stomach, large and small intestine, liver, spleen, skeletal muscle, kidney and lymphatic nodes were performed to search for amastigote nests. The organs were fixed with a $10 \%$ formaline buffered solution, and processed and embedded in parafin. Ten serial section of $7 \mu \mathrm{m}$ using an American Optical microtome, were made of each organ. All slides were stained with hematoxylin-eosin (H \& E). One hundred fields of each section were observed at a 400X magnification.

\section{RESULTS}

Isolates - T. cruzi strains were isolated in the culture medium obtained from a pig in the town of La Tigra and from a dog in the town of Acamilpa.

Virulence in mice - The pigs' isolate produced parasitemia at the sixth day; the maximum num- 
ber of parasites was $76 \times 10^{6}$. Six mice died between the 17th and 36th day afeter inoculation when the parasitemia had disappeared. The dogs' isolate showed less virulence once inoculated in a mouse; parasitemia was detected after nine days of inoculation with a maximum number of $47 \times 10^{6}$ parasites. Eight mice died between the 20th and 44th day, when the parasites in blood had disappeared.

Histopathology in mice - The pigs' isolate produced amastigote nests in the heart, with an average of 150 per 100 fields, and the muscle with 73 per 100 fields. The dogs' isolate produced amastigote nests in the heart, with an average of 160 nests per 100 fields $(100 \mathrm{X})$, the muscle with 90 , and the brain with 15 per 100 fields. tive.

Xenodiagnosis - All xenodiagnoses were nega-

Serology of field samples - The indirect haemagglutination test was positive with a titer of $1: 16$ for the pig and the dog.

In addition to these two cases proven by serology and isolation of the parasite, we found to be seropositive the following reservoirs, with titers of $1: 16$ or more: nine canines with titer of $1: 16$ and three with 1:32; one female bovine with 1:32; two pigs with 1:16; and another pig with 1:32 (Table II).

\section{TABLE II}

Antibody titers by $\mathrm{HAI}^{a}$ test in 76 mammals reservoirs in Morelos

\begin{tabular}{llllr}
\hline Reservoir & Negative & $1: 16$ & $1: 32$ & Total \\
\hline Dog & $37(76 \%)$ & $9(18 \%)$ & $3(6 \%)$ & 49 \\
Pig & $17(85 \%)$ & $2(10 \%)$ & $1(5 \%)$ & 20 \\
Ox & $3(75 \%)$ & 0 & $1(25 \%)$ & 4 \\
Sheep & $2(100 \%)$ & 0 & 0 & 2 \\
Goat & $1(100 \%)$ & 0 & 0 & 1 \\
\hline
\end{tabular}

$a$ : indirect haemagglutination

\section{DISCUSSION}

Although research regarding T. cruzi reservoirs are scarce in Mexico (Tay et al. 1980, 1992, Velasco-Castrejón \& Guzmán-Bracho 1986) it is worthwhile to point out that determining natural infection in all the studied specimens is important mainly because of their close relation to humans.

We report here in the first case of natural infection in a pig in Mexico and confirm again the dog as a reservoir. The dog and the cat have been described as the main reservoirs in Latin America by several authors.

The isolates obtained from humans studied in Mexico have shown greater virulence (assessed by the parasite's tissular tropism and the number of amastigote nests) than the isolates from the transmisor (Tay 1973, Salazar-Schettino et al. 1978). In South America, it has been observed that the virulence of this parasite increases as it passes through the reservoir. This study confirms the aforementioned statement based on the fact that isolates from the transmisor found in the same location (Bautista 1993) showed less virulence than that found in the reservoirs reported in this study.

Xenodiagnoses were negative even in the cases in which the parasite was isolated, probably because they were performed only one time and in few specimens (five), of wich two specimens used for the xenodiagnosis corresponding to the pig and three used for the dog died before of four months.

The infection detected in domestic and peridomestic mammals is an important risk indicator, not only because the infection might remain in nature, as supported by this research, but for the risk that this infection could be acquired by humans.

\section{REFERENCES}

Aguirre PE 1947. Presencia de Trypanosoma cruzi en mamíferos y triatomideos de Monterrey, Nuevo León, México. Arch Med Mex 5: 350-358.

Bautista N 1993. Estudio de Transmisores de Trypanosoma cruzi en el Estado de Morelos. MSc Thesis, UNAM, Facultad de Ciencias, México, 65 pp.

Beltrán E 1949. Hallazgo de Schizotrypanum cruzi en una rata (Rattus norvegicus) de la ciudad de México. Rev Soc Méx Hist Nat 10: 15-18.

Brumpt E, Mazzotti L, Brumpt LC 1939. Enquetes épidémiologiques sur la maladie de C. Chagas au Mexique (1). Réduvidés vecteurs. Animaux réservoirs de virus. Cas humains. Ann Parasitol 17: 299-312.

Domínguez A, Espinoza E 1988. Estudio de reservorios silvestres de Trypanosoma cruzi en el Estado de Oaxaca, México. Bol Chil Parasitol 43: 64-65.

Espinoza-Medinilla E, Zárate LG, Zárate RJ, Morales G, Gómez-Priego A 1992. Estudios sobre reservorios de Trypanosoma cruzi en Chiapas, México, p. 110. Memorias I Encuentro Hispanoamericano de Parasitología. V Centenario de América. Capítulo México

Galaviz-Silva L, Arredondo-Cantu JM 1992. Primer reporte de Neotoma micropus (Rodentia) como reservorio de Trypanosoma cruzi en México. Bol Chil Parasitol 47: 54-57.

Guzmán-Bracho C 1985. Enfermedad de Chagas en Progreso, Jiutepec, Mor. I. Encuesta Seroepidemilógica. Tesis de Especialidad. Instituto de Salubridad y Enfermedades Tropicales, Secretaria de Salud. México, 46 pp.

Mazzotti L 1940. Dos casos de enfermedad de Chagas en el Estado de Oaxaca. Gac Med Mex 70: 417-420.

Mazzotti L, Dias E 1949. Resumen de los datos publicados sobre la Enfermedad de Chagas en México. Rev Soc Mex Hist Nat 10: 103-111.

Parra TL, Cervantes FA, Salazar, PM de Haro I 1990. 
Estudio de reservorios de Trypanosoma cruzi en el Estado de Morelos, República Mexicana, p. 48. Memorias de la Reunion Nacional sobre Enfermedad de Chagas, Universidad Autónoma de Nayarit.

Perrín T, Dias E, Brenes M 1947. Nota previa sobre primeiras comprovações sorológicas da doenca de Chagas no México. Mem Inst Oswaldo Cruz 45: 395-400.

Salazar-Schettino PM, Jiménez MJ, Tay J, Cárdenas RL 1978. Estudio comparativo de la patogenicidad de cuatro cepas de $T$. cruzi en el ratón blanco. Rev Latinoamer Microbiol 20: 51-57.

Salazar-Schettino PM, Bucio MI, de Haro I, Tay J, Alonso T 1987. Reservorios y transmisores de Trypanosoma cruzi en el Estado de Oaxaca. Sal Publ Mex 29: 26-32.

Tay J, Gutiérrez M, Salazar P, Castillo M, Ortega-G M 1973. Estudios sobre seis cepas mexicanas de Trypanosoma cruzi. Rev Inv Salud Publica (Mex) 33: 67-76.

Tay J, Salazar-Schettino PM, Velasco M, Haro I de, García YY, Gutiérrez QM 1979. Estudio epidemiológico de la Enfermedad de Chagas en el Estado de Jalisco, República Mexicana. Sal Publ Mex 21: 145-149.

Tay J, Salazar-Schettino PM, Bucio MI, Zárate R, Zárate L 1980. La enfermedad de Chagas en la República Mexicana. Sal Publ Mex XXII: 409-450.

Tay J, Schenone H, Sanchez JT, Robert L 1992. Estado actual de los conocimientos sobre la Enfermedad de Chagas en la República Mexicana. Bol Chil Parasitol 47: 43-53.

Velasco CO, Romero RL, Mendiola JG 1976. Contribución de la Enfermedad de Chagas en México. Observaciones epidemiológicas en Tepechitlan, Zacatecas. Rev Invest Sal Publ (Mex) 30: 197-204.

Velasco-Castrejón O, Guzmán-Bracho C 1986. Importancia de la Enfermedad de Chagas en México. Rev Lat-amer Microbiol 28: 275-283.

Velasco-Castrejón O 1991. La Enfermedad de Chagas. Instituto Nacional de Diagnóstico y Referencia Epidemiológicos, SSA. Publicación Técnica del INDRE \# 8 (Mex), 150 pp. 